\title{
Pendekatan Implementasi Model Substractive Clustering Dalam Memetakan Dan Klasifikasi Data Perilaku Konsumen Listrik Tegangan Rendah Studi Kasus: Pelanggan PT PLN (Persero) UP3 Cengkareng
}

\author{
Yozika Arvio $^{1}$; Meilinda Devi Anjarwati ${ }^{2}$;riansyah BM Sangadji ${ }^{3}$; Hengki Sikumbang ${ }^{4}$ \\ 1, 2, 3, 4 Departemen Informatika, Sekolah Tinggi Teknik PLN \\ 1yozika@sttpln.ac.id
}

\begin{abstract}
Electrical energy is one of the most important and vital human needs that cannot be released from daily needs. Customers also have begun to be critical of the purchase costs that must be paid every month. So by increasing electricity rates, improving efficiency in the use of electric power is a major consideration. The Advanced Measurement Infrastructure System (AMI) provides information on the use of granular energy for needs and customers. The IT system at AMI one of which uses EMS (Energy Management System) is an application to collect data from every smart meter installed in the customer, to store it in a database, and to connect the analysis and statistics of the data stored below. In this study aims to provide an analysis of electricity usage patterns by implementing AMI / Smart meters PT. PLN (Persero) by conducting a cluster of 1 phase and 3 phase electricity usage in customers of PT PLN (Persero) UP3 Cengkareng, namely the distribution booths DK60, TG70 and DK242 for 4 months, from November 2018 to February 2019. From the results of the study sought for customers 1 phase DK 60 with a radius of 0.5 produces 1 cluster that is stable every month depending on the customer at this substation is a household class customer, TG 70 requires stable and spending usage in December 2018, and DK 242 fix stable and use customers in the month December 2018 and January 2019, while for 3-phase DK 60 customers tend to be unstable because the customers of this apartment are different, starting from shops, production sites, and CV.TG 70 substations are predominantly places of worship, namely mosques and mosques, so the average use of mosques is higher, and for DK 242 3-phase customers need to be stable and use the highest in January 2019.
\end{abstract}

Keywords: AMI, System, EMS, Distribution Substation, Phase

\begin{abstract}
ABSTRAK
Energi listrik merupakan salah satu kebutuhan manusia yang sangat penting dan vital yang tidak dapat dilepaskan dari keperluan sehari-hari. Pelangganpun sudah mulai kritis terhadap biaya pemakaian yang harus dibayar setiap bulannya. Maka dengan semakin tingginya tarif listrik, maka tuntutan efisiensi dalam pemakaian daya listrik menjadi pertimbangan utama.Advanced Metering Infrastructure (AMI) system memberikan informasi penggunaan energi granular untuk utilitas dan pelanggan. IT sistem pada AMI salah satunya menggunakan EMS (Energy Management System) adalah suatu aplikasi untuk mengumpulkan data dari setiap smart meter yang terpasang dipelanggan, untuk menyimpannya ke database, dan untuk menunjukkan analisis dan statistik dari data yang disimpan di bawah kondisi spesifik yang dipilih oleh pengguna.Dalam penelitian ini bertujuan untuk memberikan analisa pola beban pemakaian listrik dengan implementasi AMI/Smart meter PT. PLN (Persero) dengan melakukan cluster terhadap pemakaian listrik 1 phasa dan 3 phasa di pelanggan PT PLN (Persero) UP3 Cengkareng yaitu gardu distribusi DK60, TG70 dan DK242 selama 4 bulan yaitu dari bulan November 2018 s.d Februari 2019. Dari hasil penelitian didapat untuk pelanggan 1 Phasa DK 60 dengan radius 0.5 menghasilkan 1 cluster yaitu cenderung stabil setiap bulannya dikarenakan pelanggan pada gardu tersebut merupakan pelanggan golongan rumah tangga, TG 70 cenderung stabil dan mengalami kenaikan pemakaian pada bulan Desember 2018, dan DK 242 cenderung stabil dan pemakaian tertinggi pelanggan pada bulan Desember 2018 dan
\end{abstract}


PETIR: Jurnal Pengkajian dan Penerapan Teknik Informatika

Vol. 12, No. 2, September 2019, P-ISSN 1978-9262, E-ISSN 2655-5018

Januari 2019, sedangkan untuk pelanggan 3 phasa DK 60 cenderung tidak stabil dikarenakan pelanggan digardu tersebut bervariasi, mulai dari Toko, Tempat produksi, dan CV. Gardu TG 70 dominan tempat ibadah yaitu Masjid dan Mushola, sehingga pemakaian rata-rata lebih tinggi Masjid, dan untuk DK 242 pelanggan 3 phasa cenderung stabil dan pemakaian tertinggi pada bulan Januari 2019.

Kata kunci: AMI, System, EMS, Gardu Distribusi, Phasa 


\section{PENDAHULUAN}

\subsection{Latar Belakang}

Listrik saat ini sudah merupakan kebutuhan pokok masyarakat. Bukan hanya sekedar menyala, namun tuntutan pelanggan tentang kualitas penyaluran dan keandalan sudah semakin meningkat. Pelangganpun sudah mulai kritis terhadap biaya pemakaian yang harus dibayar setiap bulannya. Maka dengan semakin tingginya tarif listrik, maka tuntutan efisiensi dalam pemakaian daya listrik menjadi pertimbangan utama. Efisiensi penggunaan daya listrik dipengaruhi oleh banyak faktor. Diantaranya adalah kualitas daya listrik. Kualitas daya listrik sangat dipengaruhi oleh penggunaan jenis-jenis beban tertentu yang mengakibatkan turunnya efisiensi. Jenis-jenis beban yang mempengaruhi kualitas daya listrik adalah beban-beban induktif, seperti; motor induksi, kumparan, ballast, lampu TL. Demikian juga beban-beban non linier seperti; konverter dan inverter untuk drive motor, mesin las, furnace, komputer, ac, tv, lampu TL dan lain-lain. beban-beban induktif akan menurunkan faktor daya sehingga dapat menyebabkan denda apabila faktor daya kurang dari 0.85 lag, sedangkan beban-beban non linier tersebut menimbulkan harmonisa yang dampaknya akan mempengaruhi kualitas daya, sehingga menimbulkan kerugian - kerugian.

Advanced Metering Infrastructure (AMI) system memberikan informasi penggunaan energi granular untuk utilitas dan pelanggan. AMI adalah hardware intensif dan melibatkan penggantian meter atau modul pada setiap titik akhir. Sebuah sistem AMI memiliki tiga komponen utama: (1) smart meters (and associated communication modules), (2) a communication network, dan (3) AMI back office information technology (IT) systems to manage the two way communications enabled oleh sistem AMI. IT sistem pada AMI salah satunya menggunakan EMS (Energy Management System) adalah suatu aplikasi untuk mengumpulkan data dari setiap smart meter yang terpasang dipelanggan, untuk menyimpannya ke database, dan untuk menunjukkan analisis dan statistik dari data yang disimpan di bawah kondisi spesifik yang dipilih oleh pengguna. Operator/pengguna dapat memeriksa konsumsi energi (Aktif / Reaktif) setiap klien / meter, status komunikasi antara masingmasing smart meter dan DCU (Data Concentration Unit) dan antara sistem DCU dan EMS, status smart meter, dan kualitas daya seperti Tegangan/Faktor Daya/ Frekuensi. Sistem EMS dapat mengekspor data penagihan ke format excel.

Oleh sebab itu, untuk dapat mengetahui pola pemakaian konsumsi selama sebulan untuk pelanggan 1 (satu) fasa dan 3 (tiga) fasa dibutuhkan model subtractive clustering. 


\section{METODE PENELITIAN}

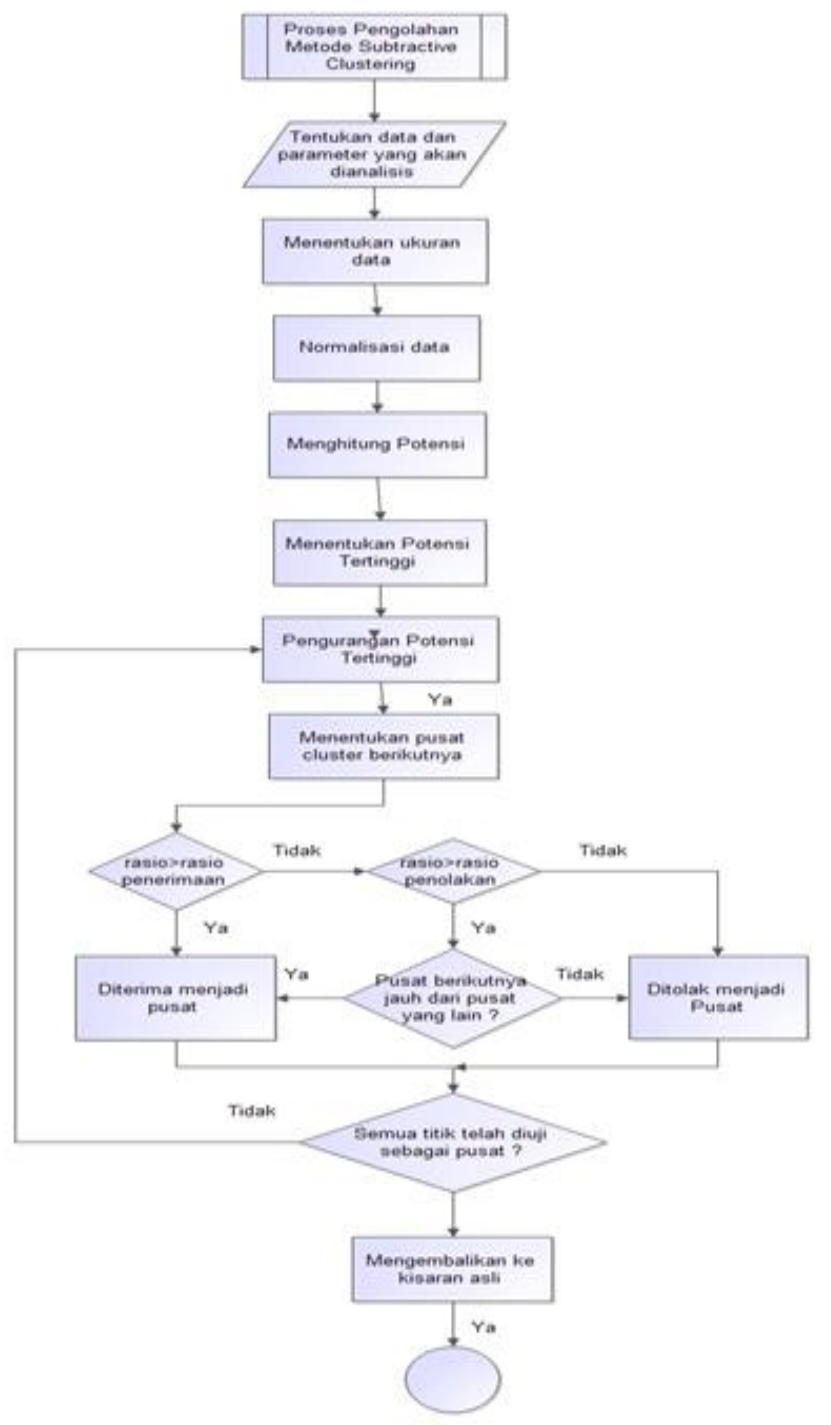

Gambar 1. Diagram Alir Algoritma Fuzzy Subtractive Clustering

\subsection{Kebutuhan Input}

Data yang menjadi kebutuhan input dalam sistem ini adalah data konsumsi pemakaian listrik 1 phasa dan 3 phasa selama 4 bulan dari bulan November 2018 s.d Februari 2019 pada pelanggan PLN UP3 Cengkareng di 3 Gardu yaitu Gardu DK60, TG70 dan DK242.

Variabel yang digunakan pada penelitian ini adalah:

a) Variabel 1: last month usage (jumlah pemakaian listrik bulan sebelumnya)

b) Variabel 2: current month usage (jumlah pemakaian listrik yang berjalan)

\subsection{Kebutuhan Proses}

Kebutuhan proses disini yaitu variable dan parameter yang digunakan untuk mengolah data secara umum. Adapun spesifikasi dari perangkat lunak dan keras yang penulis gunakan dalam penelitian ini adalah sebagai berikut:

1. Variabel

$\mathrm{X} 1=$ lastmonthusage

$\mathrm{X} 2=$ curentmontusage 
2. Menentukan nilai parameter

Nilai parameter yang digunakan merupakan hasil dari percobaan yang telah dilakukan sehingga didapatkan nilai parameter yang maksimal.
a. $r$ (jari-jari $)=0.8$
b. $\mathrm{q}$ (squash factor $)=1.25$
c. accept ratio $=0.8$
d. reject ratio $=0.2$

\subsection{Kebutuhan Output}

Output yang diharapkan dari penelitian ini adalah berupa aplikasi yang menggambarkan clustercluster data.

\section{HASIL DAN PEMBAHASAN}

Untuk mendapatkan kurva beban pelanggan, dibutuhkan pencatatan data pemakaian $\mathrm{kWh}$ yang dapat direkam pada interval waktu tertentu. Data kurva beban yang diikuti dengan perhitungan load factor dapat dimanfaatkan untuk berbagai keperluan dalam rangka penyusunan skema tarif tenaga listrik dan perhitungan subsidi listrik ke pelanggan.

Pada proses sistem AMI ini data didapat dari DCU yang terhubung ke meter pelangan menggunakan jaringan internet sehingga beberapa fitur yang dapat dibaca di EMS adalah usage info, power quality, consumption data, TDU data, Equip Manage, dan Client Manage. Pada penelitian ini data yang digunakan pada fitur Consumption data yaitu last month usage $(\mathrm{kWh})$ dan current month usage $(\mathrm{kWh})$.

\subsection{Gardu Distribusi DK 60 daerah Interkota}

-Summary Usage(kWh)

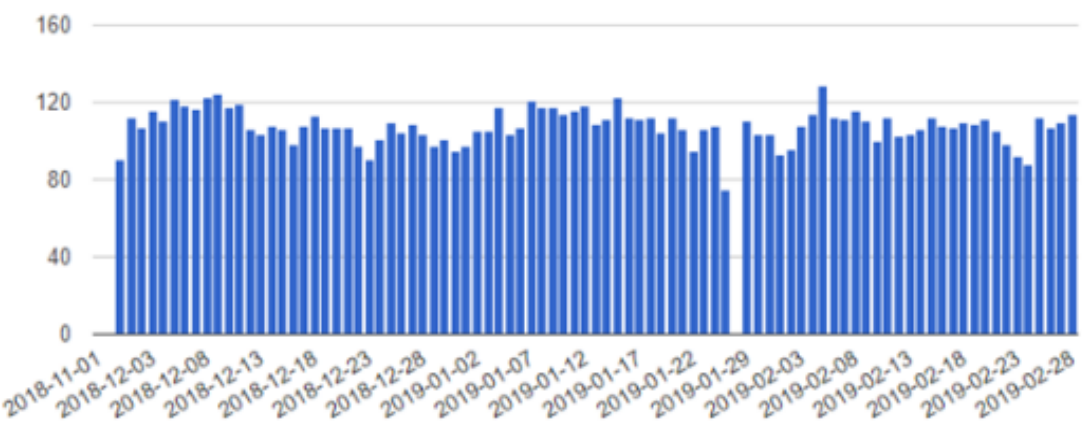

Gambar 2. Grafik Summary Usage DK 601 Phasa

Pembentukan cluster data pelanggan pada gardu DK 60, dilihat dari pemakaian selama 4 bulan yaitu pada bulan November 2018 s.d Februari 2019 untuk pelanggan 1 phasa di gardu DK60. 


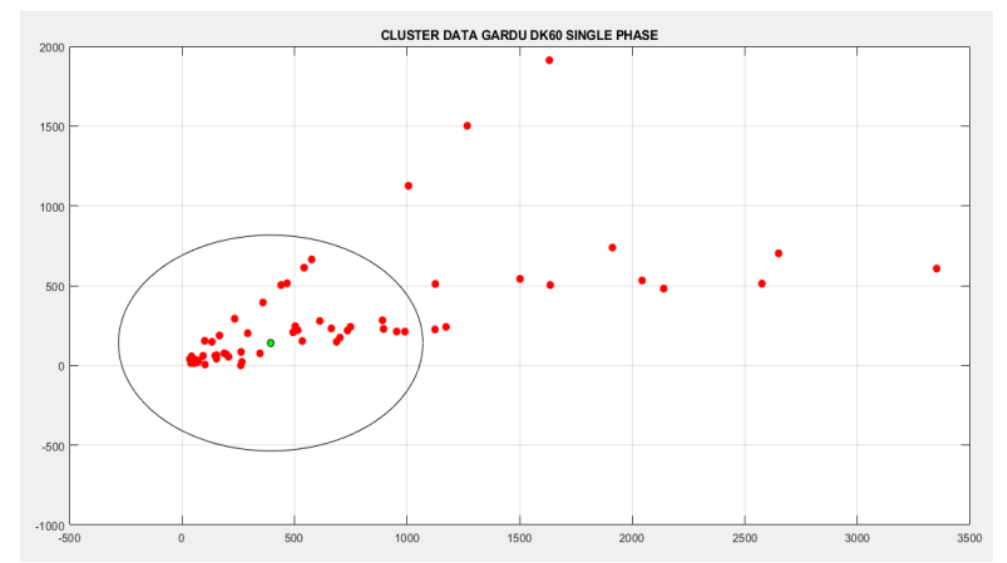

Gambar 3. Hasil Proses Cluster DK 601 Phasa

Pada proses di gambar 3.2 dapat dilihat bahwa radius 0.5 menghasilkan 1 cluster, pada grafik pemakaian di gardu DK 60 untuk pelanggan 1 phasa cenderung stabil setiap bulannya dikarenakan pelanggan pada gardu tersebut cenderung dari pelanggan golongan rumah tangga.

Sedangkan pembentukan cluster data pelanggan pada gardu DK 603 Phasa, seperti berikut:

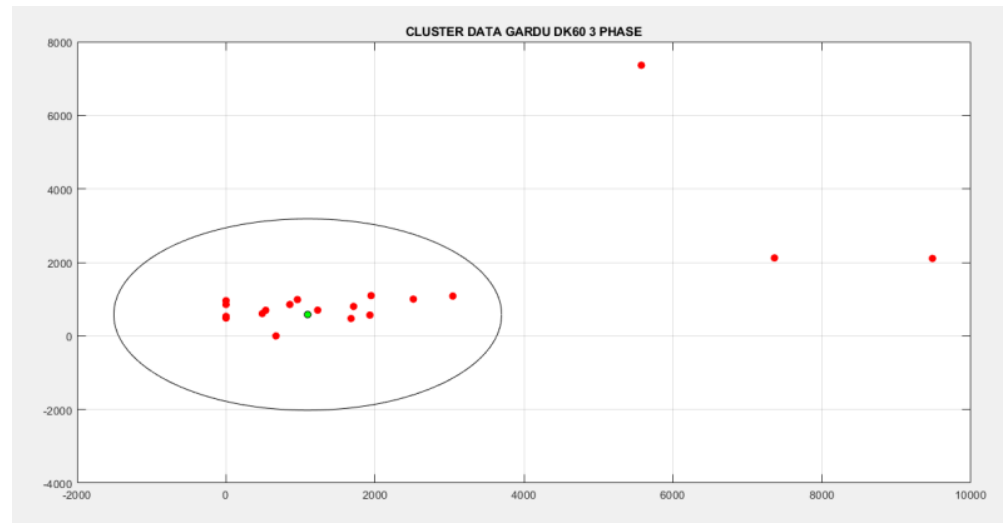

Gambar 4. Hasil Proses Cluster DK 603 Phasa

Pada proses di gambar 3.3 dapat dilihat bahwa radius 0.5 menghasilkan 1 cluster, dapat dilihat pada grafik pemakaian di gardu DK 60 untuk pelanggan 3 phasa cenderung tidak stabil karena pelanggan 3 phasa di gardu tersebut bervariasi.

$$
\text { - Summary Usage(kWh) }
$$

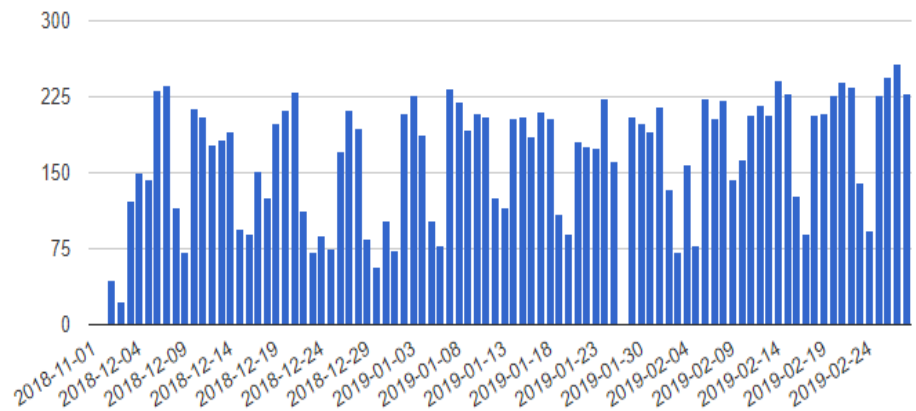

Gambar 5. Grafik Summary Usage DK 603 Phasa 


\subsection{Gardu Distribusi DK 70 daerah Duri Kosambi}

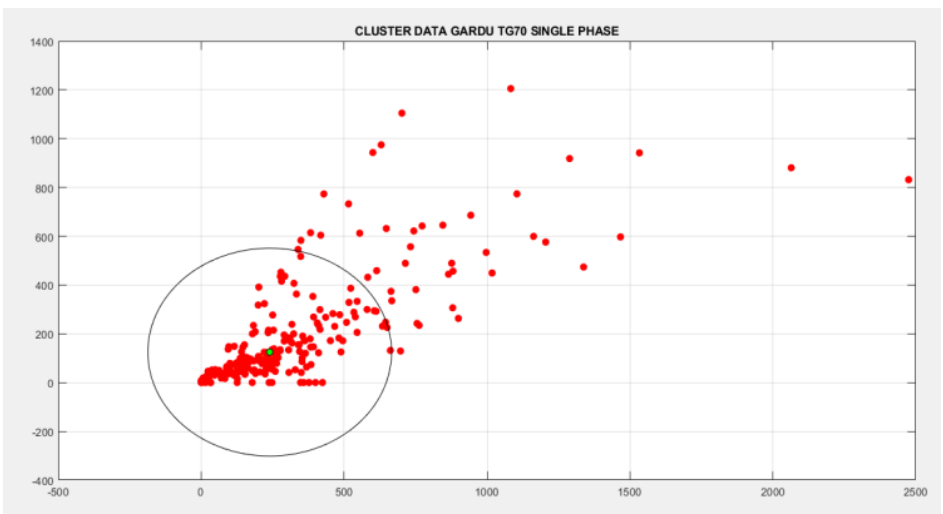

Gambar 6. Hasil Proses Cluster TG 701 Phasa

Pada proses di gambar 3.5 dapat dilihat bahwa radius 0.5 menghasilkan 1 cluster, dapat dilihat pada grafik pemakaian di gardu DK 60 untuk pelanggan 1 phasa cenderung stabil dan mengalami kenaikan pemakaian pada bulan Desember 2018. Dengan rata-rata pemakaian harian dapat dilihat pada grafik dibawah ini.

-Summary Usage(kWh)

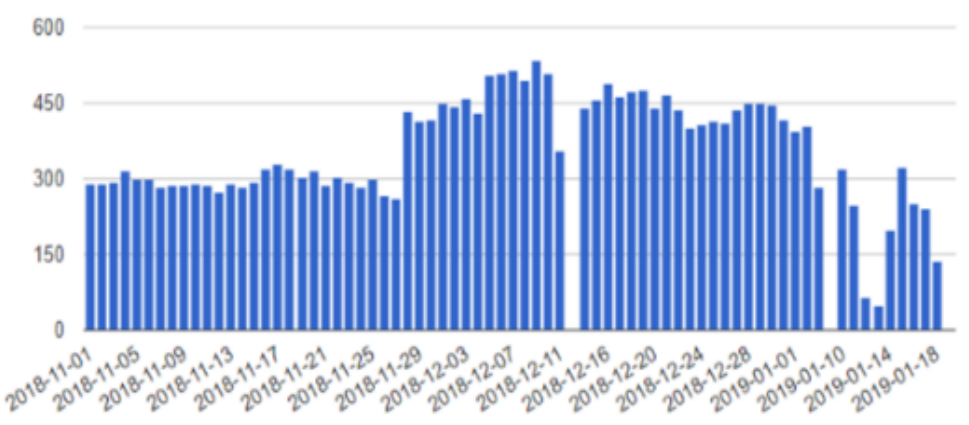

Gambar 7. rafik Summary Usage TG 701 Phasa

Sedangkan pembentukan cluster data pelanggan pada gardu TG70 3 Phasa, seperti berikut:

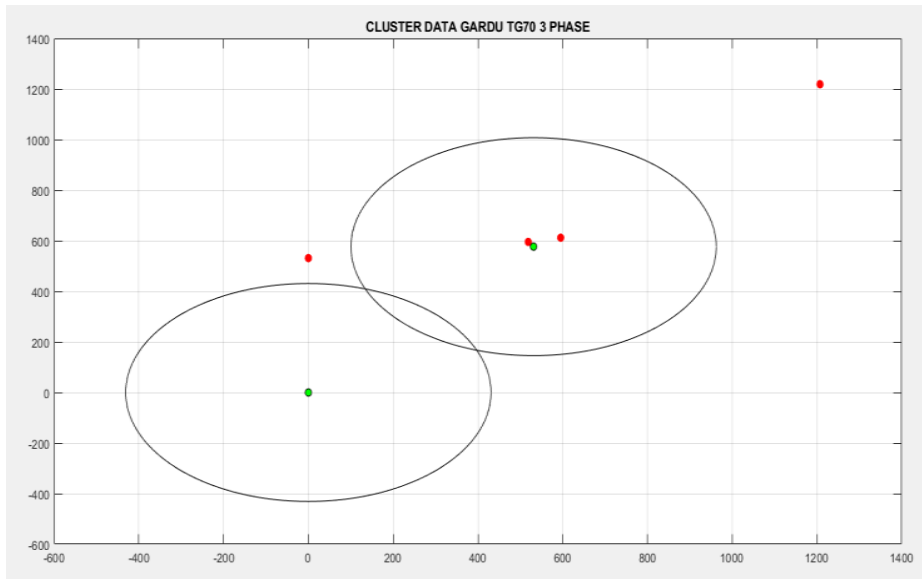

Gambar 8. Hasil Proses Cluster TG 703 Phasa 
Pada proses di gambar 3.7 dapat dilihat bahwa radius 0.5 menghasilkan 2 cluster, dapat dilihat pada grafik terdapat dua pelanggan yaitu dari Mushola dan Masjid, pemakaian Masjid lebih tinggi dibandingkan dengan Mushola. Dengan rata-rata pemakaian harian dapat dilihat pada grafik dibawah ini.

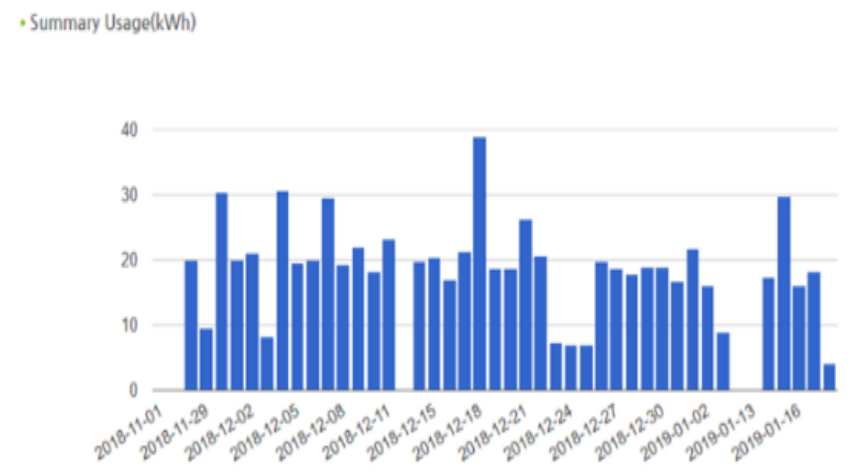

Gambar 9. Grafik Summary Usage TG 703 Phasa

\subsection{Gardu Distribusi DK 242 daerah Haji Mali}

Adapun pembentukan cluster data pelanggan pada gardu DK 242, dilihat dari pemakaian selama 4 bulan yaitu pada bulan November 2018 s.d Februari 2019 untuk pelanggan 1 phasa, adalah sebagai berikut:

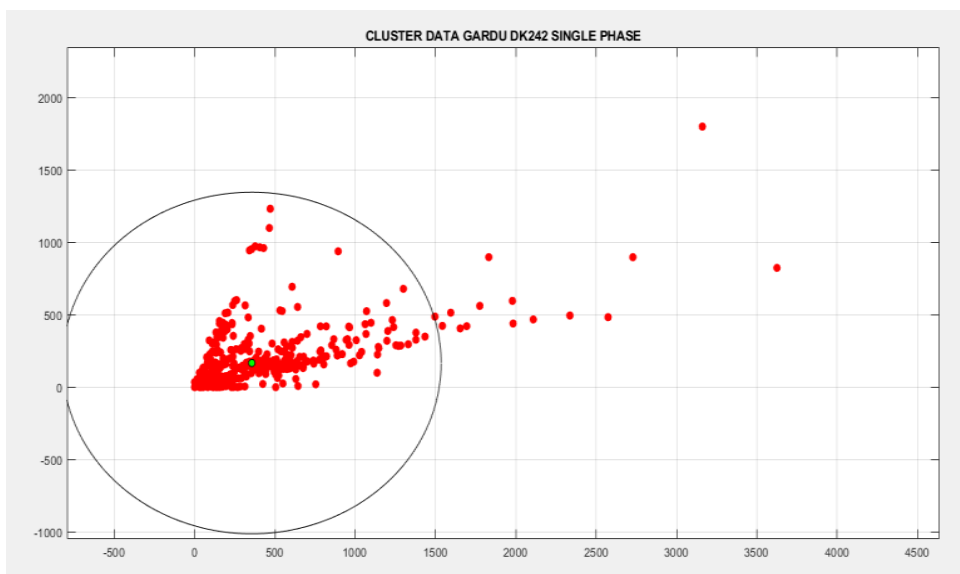

Gambar 10. Hasil Proses Cluster DK 2421 Phasa

Pada proses di gambar 3.9 dapat dilihat bahwa radius 0.5 menghasilkan 1 cluster, total pelanggan pada gardu DK242 merupakan paling banyak dikarenakan banyak pelanggan yang bisa dilakukan pemasangan dan dapat dilihat pada grafik bahwa pemakaian listrik cenderung stabil dan pemakaian tertinggi pelanggan pada bulan Desember 2018 dan Januari 2019. 


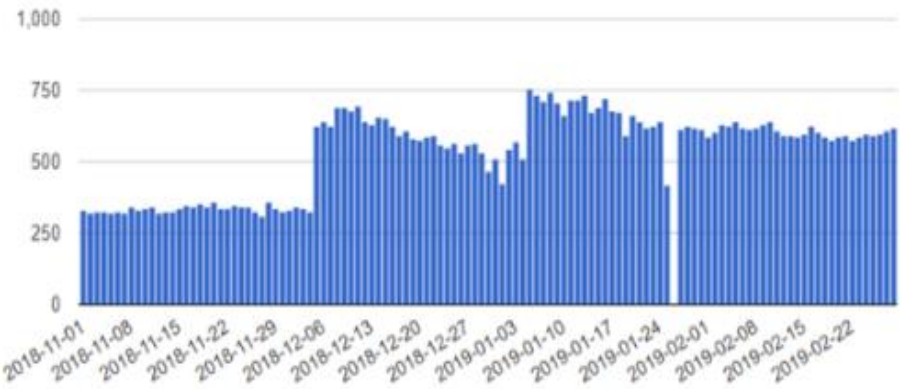

Gambar 11. Grafik Summary Usage DK 2421 Phasa

Sedangkan pembentukan cluster data pelanggan pada gardu DK 2423 Phasa, seperti berikut:

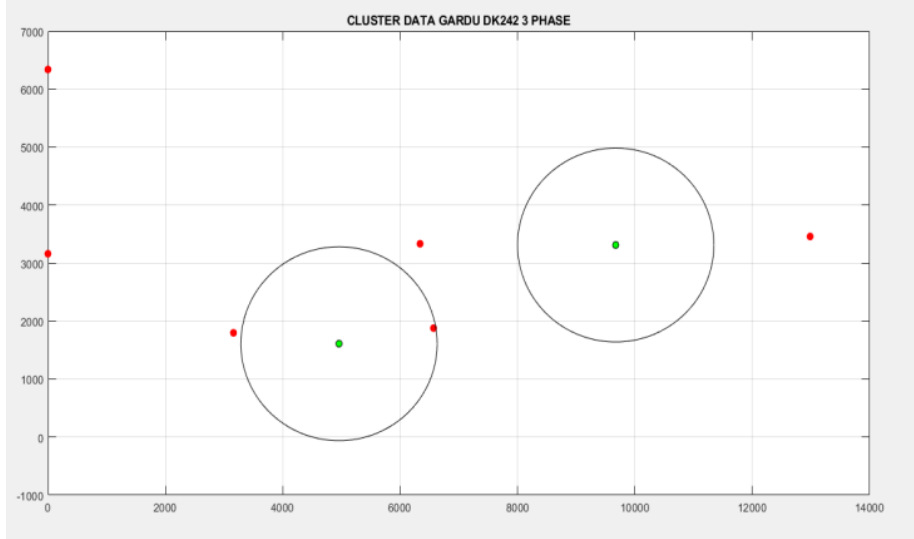

Gambar 12. Hasil Proses Cluster DK 2423 Phasa

Pada proses di gambar 3.11 dapat dilihat bahwa radius 0.5 menghasilkan 2 cluster dapat dilihat pada grafik bahwa pemakaian pelanggan cenderung stabil dan pemakaian tertinggi pada bulan Januari 2019.

- Summary Usage(kWh)

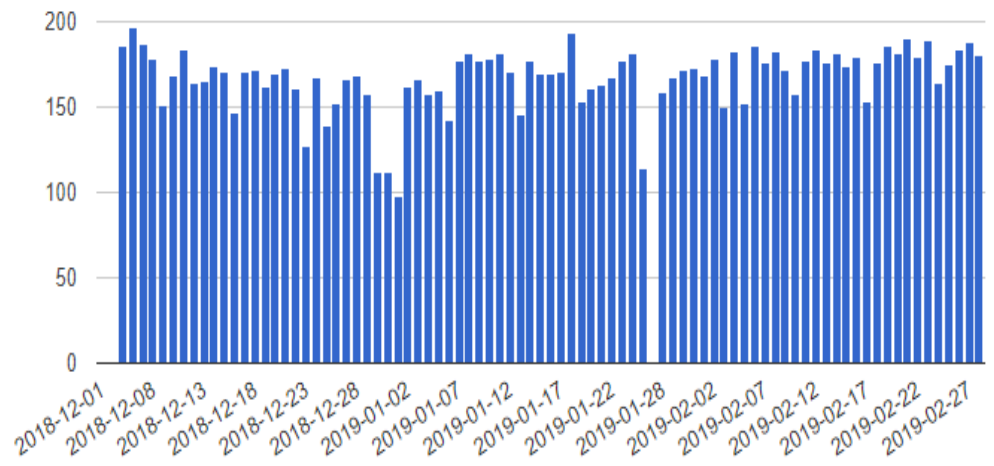

Gambar 13. Grafik Summary Usage DK 2423 Phasa Dengan rata-rata pemakaian konsumsi listrik sebesar $\pm 150 \mathrm{kWh}$ perhari. 


\section{KESIMPULAN DAN SARAN}

\subsection{Kesimpulan}

Berdasarkan hasil penelitian dan pembahasan yang telah dilakukan dapat diambil beberapa kesimpulan, antara lain:

1. Dengan menggunakan model subtractive clustering dapat menentukan pola beban meter pelanggan PLN 1 phasa dan 3 phasa.

2. Pemakaian rata-rata pelanggan golongan rumah tangga 1 phasa cenderung stabil setiap bulannya, akan tetapi pada bulan-bulan tertentu mengalami peningkatan seperti pada bulan Desember ketika libur sekolah sehingga aktivitas lebih banyak diluangkan dirumah.

3. Sedangkan untuk pelanggan golongan Bisnis 3 phasa rata-rata pemakaian cenderung meningkat dibulan Januari, dengan rata-ratapemakaian konsumsi listrik sebesar $\pm 150 \mathrm{kWh}$ perhari.

4. Sistem AMI di PT PLN Persero UP3 Cengkareng menunjukkan bahwa meter AMI secara teknis cukup untuk digunakan dalam sistem tegangan rendah PT PLN (Persero) dan hasilnya menunjukkan bahwa banyak peluang peluang yang dapat diambil dari fitur AMI.

\subsection{Saran}

Berdasarkan penelitian sistem AMI dan hasil pengujian di UP3 Cengkareng, yang mengindikasikan banyak peluang peningkatan layanan dan operasional untuk PT PLN (Persero) dan juga meningkatkan kepuasan pelanggan, direkomendasikan untuk memiliki standar nasional untuk sistem AMI di Indonesia.

\section{DAFTAR PUSTAKA}

[1] Kusuma Vianti, Furqon M. Tanzil, Muflikhah Lailil, 2017, "Implementasi Metode Fuzzy Subtractive Clustering Untuk Pengelompokan Data Potensi Kebakaran Hutan/Lahan”, Jurnal Pengembangan Teknologi Informasi, dan Ilmu Komputer, Vol. 1, No. 9, Juni 2017, hlm. 876884.

[2] EMS Manual Book, Tide, Co., Ltd, 2016.

[3] Nugroho, Ari Wahyu, 2018, "Prakiraan Konsumsi Energi Listrik Jangka Panjang Di Provinsi D.I. Yogyakarta Menggunakan Logika Fuzzy".

[4] Kuswanto Riski Agustin, Wrahatnolo Tri, 2019, "Prakiraan Beban Listrik Jangka Pendek Untuk Jaringan Distribusi 20 KV Berbasis Fuzzy Logic (Studi Kasus Pada APJ. Surabaya Selatan Dan Surabaya Barat)", Jurnal Teknik Elektro. Volume 08 Nomor 02 Tahun 2019, 333 -340 .

[5] Gohil, Priti, Gupta, Monika. 2014. "Short Term Load Forecasting Using Fuzzy Logic". International Journal of Engineering Development and Research (IJEDR). Vol. 2: hal. 127130.

[6] Setiawan, Bangkit and, Jatmiko, (2018), "Analisa Efisiensi Kebutuhan Beban Pada Beberapa Jenis Lampu terhadap Tahap Pembelajaran”.

[7] IEEE. Vol. 9, Sept 2018, page 5113-5122, "Identifying Topology of Low Voltage Distribution Networks Based on Smart Meter Data".

[8] [Siregar, R. R. A., Sikumbang, H., \& Sangadji, I. B. (2018). KWh Meter Smart Card Model Token For Electrical Energy Monitoring. In MATEC Web of Conferences (Vol. 218, p. 03002). EDP Sciences.

[9] Siregar, R. R. A., Sikumbang, H., \& Pasaribu, R. J. (2018). Model Pengisian Pulsa Listrik Kwh Meter Dengan Smart Card. JETri Jurnal Ilmiah Teknik Elektro, 16 (1), 39 54. 
[10] T. Nisa, R. Siregar, And W. Suliyanti, "Estimasi Daya Beban Listrik Pada Gardu Induk Cengkareng Dengan Menggunakan Metode Time Series Model Dekomposisi”, Teknologia, Vol. 1, No. 2, Apr. 2019.

[11] Sangadji, I., \& Arvio, Y. (2018, March). Dynamic Segmentation Of Behavior Patterns Based On Quantity Value Movement Using Fuzzy Subtractive Clustering Method. In Journal of Physics: Conference Series (Vol. 974, No. 1, p. 012009). IOP Publishing.

[12] BM Sangadji, Iriansyah. (2012). Komparasi Model Regresi Untuk Prakiraan Beban Listrik Jangka Pendek Menggunakan Koefisien Dan Pembangkitan Data Random. 